\title{
BODY COMPOSITION AMONG UNIVERSITY FEMALE ATHLETES OF TEAM SPORTS
}

\author{
COMPOSIÇÃO CORPORAL ENTRE ATLETAS UNIVERSITÁRIAS DE ESPORTES COLETIVOS
}

Artigo Original

Artículo Original

\section{COMPOSICIÓN CORPORAL ENTRE ATLETAS UNIVERSITARIAS DE DEPORTES COLECTIVOS}

\begin{abstract}
Carlos Alencar Souza Alves Junior ${ }^{1}$ (Physical Education Professional) Mikael Seabra Moraes' (ID (Physical Education Professional) Cassiano Schuaste de Souza' (ID) (Physical Education Student) Giovani Costa' (ID (Physical Education Student) Diego Augusto Santos Silva' (iD) (Physical Education Professional)

1. Universidade Federal de Santa Catarina, Research Center in Kinanthropometry and Human Performance, Florianópolis, SC, Brazil.
\end{abstract}

\section{Correspondence:}

Diego Augusto Santos Silva. Federal University of Santa Catarina, Sports Center, Research Center in Kinanthropometry and Human Performance. University Campus "Reitor João David Ferreira Lima", s/no, Trindade. CEP: 88040-900. Florianópolis, SC. diegoaugustoss@yahoo.com.br

\section{ABSTRACT}

Introduction: The assessment of body composition in female athletes of different sports is important for health monitoring. Objective: To compare body composition in university athletes of different team sports (indoor soccer, flag football and volleyball). Methods: A cross-sectional study carried out with 45 female athletes, aged 18 to 35 years ( $22.8 \pm 3.55)$. The dependent variables were body fat mass (FM) and fat-free mass (FFM) measured by air displacement plethysmography. Bone mineral content, adjusted for height (BMC/height) and bone mineral density (BMD), were measured by dual energy $X$-ray absorptiometry. The independent variable was sport [flag football $(n=12)$; indoor soccer $(n=20)$; volleyball $(n=13)$ ] and the covariates were age (complete years), training volume (minutes per week) and length of time playing the sport (complete years). Analysis of covariance was used. Results: Adjusting the model for covariates, volleyball athletes (19.27 kg \pm 2.20$)$ presented higher FM values compared to the flag football $(16.00 \mathrm{~kg} \pm 1.70)$ and indoor soccer players (12.20 kg \pm 1.30$)$. There was no significant difference in FFM, BMC/height and total BMD between sports, even after adjusting for covariates. Conclusion: Volleyball athletes presented higher FM compared to flag football and indoor soccer athletes. There were no differences in FFM, BMC/height and BMD among the players of the different team sports. This study can help coaches and other sports professionals to prevent injuries to athletes in sports such as higher FM (volleyball), or to prevent diseases such as menstrual irregularities, which are common in athletes who may have low levels of body fat (indoor soccer players), this being one of the risk factors for the female athlete triad (eating disorders, menstrual irregularities and low BMD). Level of evidence III; Retrospective comparative study.

Keywords: Adipose tissue; Muscle development; Bone; Sports.

\section{RESUMO}

Introdução: A avaliação da composição corporal em atletas do sexo feminino de diferentes modalidades esportivas éimportante para o monitoramento da saúde. Objetivos: Comparar a composição corporal de atletas universitárias, de diferentes modalidades coletivas (futebol de salão, flag football e voleibol). Métodos: Estudo transversal realizado com 45 atletas do sexo feminino, com idades entre 18 e 35 anos $(22,8 \pm 3,55)$. As variáveis dependentes foram a massa gorda corporal (MG) e a massa magra (MM) medida por pletismografia por deslocamento de ar. O conteúdo mineral ósseo ajustado para estatura (CMO/estatura) e densidade mineral óssea (DMO) foram medidos por absorciometria por dupla emissão de raios $X$. As variáveis independentes foram os esportes [flag football $(n=12)$; futebol de salão ( $n$ =20); voleibol ( $n=13)$ ] e as covariáveis foram idade (anos completos), volume de treinamento (minutos por semana) e tempo de prática (anos completos). A análise de covariância foi utilizada. Resultados: Ao ajustar o modelo pelas covariáveis, as atletas de voleibol (19,27 kg $\pm 2,20)$ apresentaram valores maiores de $M G$ com relação às de flag football $(16,00 \mathrm{~kg} \pm 1,70)$ e de futebol de salão $(12,20 \mathrm{~kg} \pm 1,30)$. Não houve diferença significativa na MM, CMO/estatura e DMO total entre os esportes, mesmo depois do ajuste para as covariáveis. Conclusões: As atletas de voleibol apresentaram maior MG em comparação com as atletas de flag football e futebol de salão. Não houve diferenças em MM, CMO/estatura e DMO entre os jogadoras de diferentes modalidades coletivas. Este estudo pode ajudar treinadores e outros profissionais do esporte a prevenir lesões em atletas com maior MG (voleibol) ou prevenir doenças como irregularidades menstruais, comuns em atletas com baixos niveis de gordura corporal (futebol de salão), que é um dos fatores de risco para a síndrome da tríade da atleta feminina (distúrbios alimentares, irregularidades menstruais e baixa DMO). Nível de evidência III; Estudo retrospectivo comparativo.

Descritores: Tecido adiposo; Desenvolvimento muscular; Osso; Esportes

\section{RESUMEN}

Introducción: La evaluación de la composición corporal en atletas del sexo femenino de diferentes modalidades deportivas es importante para la monitorización de la salud. Objetivos: Comparar la composición corporal de atletas universitarias, de diferentes modalidades colectivas (fútbol de salón, flag football y vóleibol). Métodos: Estudio transversal realizado con 45 atletas del sexo femenino, con edades entre 18 y 35 años $(22,8 \pm 3,55)$. Las variables dependientes fueron la masa grasa (MG) y masa magra (MM) medida por pletismografía por desplazamiento de aire. El contenido mineral óseo ajustado para estatura (CMO/estatura) y densidad mineral ósea (DMO) fueron medidos por 
absorciometría por doble emisión de rayos X. Las variables independientes fueron los deportes [flag football $(n=12)$; fútbol de salón ( $n=20)$; vóleibol ( $n=13)$ ] y las covariables fueron edad (años completos), volumen de entrenamiento (minutos por semana) y tiempo de práctica (años completos). Fue utilizado el análisis de covariancia. Resultados: Al ajustar el modelo por las covariables, las atletas de vóleibol $(19,27 \mathrm{~kg} \pm 2,20)$ presentaron valores mayores de MG con relación a las de flag football $(16,00 \mathrm{~kg} \pm 1,70)$ y de fútbol de salón $(12,20 \mathrm{~kg} \pm 1,30)$. No hubo diferencia significativa en la MM, CMO/estatura y DMO total entre los deportes, incluso después del ajuste para las covariables. Conclusiones: Las atletas de vóleibol presentaron mayor MG en comparación con los atletas de flag football y fútbol de salón. No hubo diferencias en MM, CMO/estatura y DMO entre las jugadoras de diferentes modalidades colectivas. Este estudio puede ayudar a entrenadores y otros profesionales del deporte a prevenir lesiones en atletas con mayor MG (vóleibol) o prevenir enfermedades como irregularidades menstruales, comunes en atletas con bajos niveles de grasa corporal (fútbol de salón), que es uno de los factores de riesgo para el síndrome de la tríada de la atleta femenina (disturbios alimentarios, irregularidades menstruales y baja DMO). Nivel de evidencia III; Estudio retrospectivo comparativo.

Descriptores: Tejido adiposo; Desarrollo de músculos; Hueso; Deportes.

\section{INTRODUCTION}

Body composition assessment is important for health and an important factor for maintaining performance in athletes, as it enables the improvement of physiological attributes associated with athletic success, such as functional capacity, strength, power, agility and speed. 1,2 Body composition assessment in athletes allows coaches to evaluate training programs and adjust them throughout the year to improve performance and avoid possible injuries. ${ }^{3,4}$ Additionally, indoor soccer is an intermittent sport, which requires muscle and bone structures to sprints, repeated actions at high speed and rapid muscle contraction, factors that are inversely associated with body fat. 5 Still, although physical contact is less, it is a sport characterized by high power, speed and agility, with high intensity actions, of short duration, separated by moments of low intensity, which favor to have less amount of fat in relation to the volleyball athletes. ${ }^{6}$

High fat-free mass (FFM) percentages and low fat mass (FM) percentages are usually desirable for athletes, as they are associated with physical activities that are essential to sports performance, such as vertical jump, sprint time, relative power and maximum strength, parameters widely used in team sports. ${ }^{7,8}$ The opposite (low FFM percentage or high FM percentage) can reduce performance and cause harmful effects to health. ${ }^{7-9}$ In female athletes, menstrual dysfunction can cause eating disorder, leading to disturbances in body composition, mainly in bone health [low bone mineral content (BMC) and low bone mineral density (BMD)], interfering in both health and performance. ${ }^{10}$

Athletes who participate in different team sports have different anthropometric dimensions, reflecting in the proportionality of body shape and body composition, as they meet the specific requirements of each sport modality. ${ }^{11}$ Different team sports such as indoor soccer, flag football and volleyball present divergences in relation to the existence of different positions of athletes, whether attacking or defending, since the body composition profile required for each athlete may vary according to the sport and position in the game. Thus, understanding the differences in body composition specifically these sports is necessary. ${ }^{12-14}$

Furthermore, comparing body composition [FM, FFM, bone mineral content (BMC)/height and bone mineral density (BMD)] in different team sports can help sports medicine and health professionals who directly work with athletes to develop nutritional strategies and fitness programs., ${ }^{2,13}$ Therefore, the aim of this study was to compare body composition (FM, FFM, BMC/height and BMD) in university athletes of different team sports (indoor soccer, flag football and volleyball).

\section{METHODS}

\section{Study design}

This is a cross-sectional study conducted from September to October 2017 with university athletes from the Federal University of Santa Catarina (UFSC) located in the city of Florianópolis, Santa Catarina, Brazil. The study was approved by the Ethics Committee for Research with Human Beings at UFSC under protocol number 2.308.476. All participants signed the Free and Informed Consent Form and the research protocol is in accordance with the Declaration of Helsinki.

\section{Population and sample}

The population consisted of university athletes of different sports, regularly enrolled in undergraduate and graduate courses at the university. The study sample was non-probabilistic, in which all athletes who participated in training for regional, national and international sports competitions aged 18 to 35 years of both sexes were invited. The selection of athletes was performed through an information bank, made available by the University's Sports Department, with 179 university athletes who represented the university in sports competitions.

Of the total research population (179 athletes), 45 university athletes, flag football $(n=12)$, indoor soccer $(n=20)$ and volleyball $(n=13)$ participated in the present study.

Inclusion criteria were: 1) to be regularly enrolled in undergraduate and graduate courses at the university; 2) to have participated in at least one state, regional, national and/or international sports competition during a sports season in 2017. Exclusion criteria were: 1) athletes who were submitted to procedures that changed body composition such as bariatric surgery; 2) athletes without academic ties to the university.

The sample size was calculated a posteriori considering type I error $(a=0.05)$ and type II error $(\beta=0.80)$ to identify differences among sports with medium effect size (0.50). ${ }^{15}$ For the analysis of covariance (ANCO$V A)$, a posteriori analysis indicated that with $a=0.05$ and $\beta=0.83$, the sample of 45 athletes allowed finding differences in the comparison of means with effect size of 0.50 . All calculations were performed using $G^{*}$ Power $^{\circledast}$ software version 3.1.9.2 (Universitat Dusselfodorf, Germany).

\section{Dependent variables}

To verify FM and FM, the air displacement plethysmography (ADP) technique from BOD-POD ${ }^{\circledR}$ (Life Measurement Inc. Concord, USA) was used. The equipment was daily calibrated according to Fields ${ }^{\prime 16}$ recommendations. Subjects were evaluated with appropriate clothing, being asked to use a swimming cap to minimize the effects of hair in the air displacement analysis. During the measurement procedure, athletes 
remained seated with upright posture and normal breathing, hands resting on the thighs and feet touching the floor of the device. ${ }^{16}$ Evaluators performed up to three tests of approximately 50 seconds, totaling about three minutes of duration. At the end of the tests, the equipment automatically calculated the body density value, which, when applied to the Siri's equation, ${ }^{17}$ automatically calculated the FM. Additionally, FMM was calculated by subtracting total body mass by FM. Both variables (FFM, and FM) were expressed in kilograms (kg).

$\mathrm{BMC}$ and BMD were evaluated by dual-energy $\mathrm{x}$-ray absorptiometry (DXA) using GE ${ }^{\oplus}$ Lunar Prodigy Advance equipment and EnCore 2011 software (version 13.60.03; GE Lunar Corporation, Madison, WI, USA). Internal quality control was guaranteed by carrying out a daily calibration process with standard block provided by the manufacturer. ${ }^{18}$ During evaluations, participants were wearing a bathing suit, barefoot, without using metallic props. ${ }^{19}$ The biometric pattern reading by a specific whole-body sensor (head to toe) lasted approximately 10 minutes, while the individual remained in supine position on the device's stretcher with arms extended at the side of the body and palms facing downwards. ${ }^{18}$ BMC was evaluated in grams per centimeter $(\mathrm{g} / \mathrm{cm})$ and was adjusted for height (BMC/height). ${ }^{20}$ BMD was evaluated in grams per squared centimeter $\left(\mathrm{g} / \mathrm{cm}^{2}\right)$.

In addition, biological variation was standardized for all athletes, who received the following instructions: 1) do not perform physical activity of moderate or vigorous intensity 12 hours prior to data collection; 2) empty the bladder before the test; 3) do not drink alcohol within 48 hours prior to the test; 4) do not take diuretic medications within seven days prior to the test; 5 ) if in the menstrual period (female), the test was scheduled for another time.

The precision error for DXA was calculated through the evaluation of 30 university students who practice recreational sports with similar age and sex. All subjects were evaluated twice on consecutive days and with repositioning after each measurement. ${ }^{21}$ The accuracy error, expressed as the root mean square value with standard deviation (RMSV \pm SD), least significant change (LSC) and percentage of total body coefficient of variation (\%CV) was $0.009 \mathrm{~g} / \mathrm{cm}^{2}$ (RMSV \pm SD) ; $0.024 \mathrm{~g} / \mathrm{cm}^{2}$ or $2.4 \%$ (LSC); $0.4 \%$ (CV), which values are acceptable according to protocol of the International Society of Clinical Densitometry (ISCD) specific for athletes. ${ }^{21}$

\section{Independent variable}

The type of sport (flag football, indoor soccer or volleyball) was the independent variable. This variable was collected through self-administered questionnaire.

\section{Characterization variables}

Characterization variables were height $(\mathrm{cm})$, body mass $(\mathrm{kg})$. Age was collected using self-administered questionnaire. Height and body mass were collected according to standardization ${ }^{22}$ and measured by evaluator with level-one certification from the International Society for the Advancement of Kinanthropometry (ISAK). For height, the instrument used was Alturexata ${ }^{\circledR}$ portable stadiometer (Belo Horizonte, Brazil), with resolution in millimeters and maximum height of $213 \mathrm{~cm}$. Body mass was measured by ADP, BOD-POD ${ }^{\circledR}$ (Life Measurement Inc. Concord, USA).

\section{Covariates}

Covariates were age (in complete years), the sport training variables (training volume and practice time) investigated by means of self-administered questionnaire in which the weekly training volume was expressed in minutes per week and total practice time in sports in complete years. For analyses, these variables were treated as continuous.

\section{Statistical analysis}

For data analysis, descriptive statistics (mean and standard deviation) was initially performed. Data normality was verified through the distance between mean and median, analysis of histograms and observation of asymmetry and kurtosis (range from -3 and +3 as a criterion). ${ }^{22}$ All variables showed normal distribution. Analysis of covariance (ANCOVA) was used to compare differences in FM, FFM, BMC/height and BMD of flag football, indoor soccer and volleyball athletes. The same procedure was adopted for entering covariates in ANCOVA models: in model 1 (crude), no covariate was included; in model 2, age and the weekly training volume were included; in model 3 , the total practice time was included. Analyses were performed using the Statistical Package for the Social Sciences software (IBM SPSS Statistics, Chicago, United States), version 22.0, with 5\% significance level.

\section{RESULTS}

Forty-five university athletes, flag football $(n=12)$, indoor soccer $(n=20)$ and volleyball $(n=13)$, participated in the study, with average age of 22.8 ( \pm 3.55 ) years. The general characteristics of female athletes according to the type of sport are shown in Table 1.

The correlation matrix among all study variables was shown in Table 2. Body mass showed positive correlation with FM, FFM and BMC/height. FM and FFM showed positive correlation with BMC/height. (Table 2)

In the model $1(p=0.09)$ and model $1(p=0.06)$ no significant differences were observed between FM and type of sport. However, when controlling the interference of age, the weekly training volume and practice time (model 3, $p=0.02$ ), volleyball athletes $(19.27 \mathrm{~kg} \pm$ 2.20) presented higher FM values compared to flag football (16.00 $\mathrm{kg} \pm 1.70)$ and indoor soccer $(12.20 \mathrm{~kg} \pm 1.30)$ athletes. There was no significant difference between FFM, BMC/height and total body $\mathrm{BMD}$ and type of sport, even after adjusting for training volume and practice time. (Table 3 )

Table 1. General characteristics of female athletes according to the sport practiced.

\begin{tabular}{|c|c|c|c|c|}
\hline & $\begin{array}{c}\text { Total } \\
(n=45)\end{array}$ & $\begin{array}{l}\text { Flag Football } \\
(n=12)\end{array}$ & $\begin{array}{l}\text { Indoor Soccer } \\
(n=20)\end{array}$ & $\begin{array}{c}\text { Volleyball } \\
(n=13)\end{array}$ \\
\hline Variables & Mean $( \pm$ SD) & Mean ( \pm SD) & Mean $( \pm S D)$ & Mean $( \pm \mathrm{SD})$ \\
\hline Age (full years) & $22.80( \pm 3.55)$ & $23.81( \pm 1.37)$ & $22.50( \pm 3.30)$ & $22.80( \pm 4.88)$ \\
\hline Body mass $(\mathrm{kg})$ & $60.04( \pm 11.4)$ & $67.88( \pm 7.89)$ & $52.84( \pm 5.02)$ & $56.37( \pm 7.78)$ \\
\hline Height $(\mathrm{cm})$ & $164.00( \pm 6.57)$ & $165.15( \pm 5.06)$ & $162.30( \pm 4.57)$ & $167.17( \pm 9.56)$ \\
\hline Fat mass $(\mathrm{kg})$ & $15.03( \pm 5.59)$ & $17.24( \pm 4.63)$ & $13.06( \pm 4.65)$ & $15.93( \pm 7.10)$ \\
\hline Fat-free mass (kg) & $45.75( \pm 9.56)$ & $47.77( \pm 15.80)$ & $44.21( \pm 5.45)$ & $46.12( \pm 5.74)$ \\
\hline BMC/height (g/cm) & $15.49( \pm 1.85)$ & $15.04( \pm 1.89)$ & $15.52( \pm 1.66)$ & $15.96( \pm 2.17)$ \\
\hline $\operatorname{BMD}\left(\mathrm{g} / \mathrm{cm}^{2}\right)$ & $1.17( \pm 0.70)$ & $1.16( \pm 0.69)$ & $1.17( \pm 0.62)$ & $1.19( \pm 0.86)$ \\
\hline Training Volume (min/week) & $234.00( \pm 103.40)$ & $180.00( \pm 10.0)$ & $165.00( \pm 63.63)$ & $360.00( \pm 10.10)$ \\
\hline Practice time (full years) & $6.49( \pm 5.34)$ & $1.00( \pm 1.54)$ & $8.00( \pm 4.24)$ & $1.00( \pm 12.02)$ \\
\hline
\end{tabular}




\begin{tabular}{|c|c|c|c|c|c|c|c|c|}
\hline \multicolumn{9}{|c|}{ Pearson's Correlation Coefficient $(n=45)$} \\
\hline & Body mass $(\mathrm{kg})$ & Height $(\mathrm{cm})$ & Fat mass $(\mathrm{kg})$ & $\begin{array}{l}\text { Fat-free } \\
\text { mass (kg) }\end{array}$ & $\begin{array}{l}\text { BMC/height } \\
\text { total }(\mathrm{g} / \mathrm{cm})\end{array}$ & $\begin{array}{l}\text { BMD total } \\
\left(\mathrm{g} / \mathrm{cm}^{2}\right)\end{array}$ & $\begin{array}{c}\text { Training } \\
\text { volume (min/ } \\
\text { week) }\end{array}$ & $\begin{array}{l}\text { Practice time } \\
\text { (in years) }\end{array}$ \\
\hline Age (in years) & 0.10 & 0.12 & 0.12 & 0.05 & -0.04 & -0.13 & 0.05 & $0.29 *$ \\
\hline Body mass (kg) & - & $0.37^{*}$ & $0.31^{*}$ & $0.88^{*}$ & $0.44^{*}$ & 0.18 & -0.03 & -0.12 \\
\hline Height (cm) & & - & $0.38^{*}$ & 0.23 & 0.27 & -0.02 & 0.01 & 0.03 \\
\hline Fat mass (kg) & & & - & 0.13 & $0.37^{*}$ & -0.01 & -0.08 & -0.16 \\
\hline Fat-free mass (kg) & & & & - & $0.32^{*}$ & 0.23 & 0.01 & -0.05 \\
\hline BMC/height total (g/cm) & & & & & - & 0.81 & 0.16 & -0.64 \\
\hline BMD total $\left(\mathrm{g} / \mathrm{cm}^{2}\right)$ & & & & & & - & 0.26 & -0.02 \\
\hline Training volume (min/week) & & & & & & & - & 0.24 \\
\hline Practice time (in years) & & & & & & & & - \\
\hline
\end{tabular}

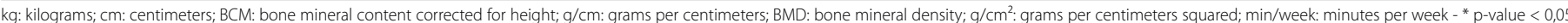
Pearson's correlation.

Table 3. Comparison of body composition in female athletes from flag football, indoor soccer and volleyball sports.

\begin{tabular}{|c|c|c|c|c|c|}
\hline Variables & $\begin{array}{l}\text { Flag Football } \\
(n=12)\end{array}$ & $\begin{array}{c}\text { Indoor Soccer } \\
(n=20)\end{array}$ & $\begin{array}{c}\text { Volleyball } \\
(n=13)\end{array}$ & & \\
\hline & Mean (SE) & \begin{tabular}{|l|} 
Mean (SE) \\
\end{tabular} & Mean (SE) & p-value & $\mathrm{ETA}^{2}$ \\
\hline \multicolumn{6}{|c|}{ Fat Mass $(\mathrm{kg})$} \\
\hline Model 1 & $16.23(4.65)$ & $13.00(4.60)$ & $15.87(7.08)$ & 0.09 & 0.12 \\
\hline Model 2 & $15.25(1.45)$ & $14.77(1.20)$ & $15.90(1.53)$ & 0.06 & 0.17 \\
\hline Model 3 & $16.00(1.70)$ & $12.20(1.30)$ & $19.27(2.20)$ & $0.02^{*}$ & 0.10 \\
\hline \multicolumn{6}{|c|}{ Fat-free mass (kg) } \\
\hline Model 1 & $47.70(5.70)$ & $44.19(5.35)$ & $46.09(5.72)$ & 0.59 & 0.03 \\
\hline Model 2 & $45.68(2.88)$ & $43.20(2.39)$ & $47.18(4.25)$ & 0.99 & 0.02 \\
\hline Model 3 & $47.69(3.22)$ & $44.20(2.48)$ & $46.17(4.33)$ & 0.99 & 0.02 \\
\hline \multicolumn{6}{|c|}{$\mathrm{BMC} / \mathrm{height}$ total $(\mathrm{g} / \mathrm{cm})$} \\
\hline Model 1 & $15.03(1.88)$ & $15.50(1.65)$ & $15.94(2.16)$ & 0.49 & 0.04 \\
\hline Model 2 & $15.02(1.88)$ & $15.50(1.65)$ & $15.94(2.15)$ & 0.66 & 0.03 \\
\hline Model 3 & $15.00(1,87)$ & $15.50(1.64)$ & $15.94(2.15)$ & 0.57 & 0.74 \\
\hline \multicolumn{6}{|c|}{ BMD total $\left(\mathrm{g} / \mathrm{cm}^{2}\right)$} \\
\hline Model 1 & $1.15(0.68)$ & $1.18(0.63)$ & $1.18(0.88)$ & 0.58 & 0.28 \\
\hline Model 2 & $1.14(0.65)$ & $1.14(0.59)$ & $1.16(0.84)$ & 0.26 & 0.97 \\
\hline Model 3 & $1.13(0.69)$ & $1.16(0.60)$ & $1.17(0.86)$ & 0.29 & 0.12 \\
\hline
\end{tabular}

\section{DISCUSSION}

The main results of the study were that female athletes who practiced volleyball presented higher FM values when compared to flag football and indoor soccer athletes, when adjusting the results by age, the volume of weekly training and total practice time in the sport. There was no difference between sports on FM, BMC / height and BMD.

When the training volume and practice time were adjusted, volleyball female athletes presented greater amount of FM in comparison to flag football and indoor soccer athletes. The factor that may explain the higher FM of volleyball athletes in comparison to the other sports refers to the very characteristic of volleyball training, which is predominantly anaerobic, which prevents the movement of body fats, slowing the mobilization of subcutaneous fat deposits. ${ }^{7,9,23}$

No significant differences were found in relation to FFM when taking into account the practice time, weekly training volume and type of sports. Study carried out with 206 female athletes of different sports (cross country, field hockey, soccer, gymnastics, lacrosse, swimming and athletics) also found no significant differences in FFM and sports. ${ }^{24}$ A possible explanation for this finding is the fact that female athletes have higher amount of testosterone, when compared to non-athlete females, which increases the amount of FFM. ${ }^{25,26}$
As a result of this study, no significant difference in BMC/height and total body BMD among flag football, indoor soccer and volleyball athletes was found. Similar to these results, studies that compared BMC and BMD of sports with osteogenic characteristics similar to sports analyzed in this study (volleyball, athletics and judo), ${ }^{27,28}$ did not identify differences in BMC and BMD among these sports. On the other hand, other studies with university athletes have identified differences in BMC and BMD among sports with different impact levels, in which sports with greater impact (e.g., volleyball, basketball and gymnastics) showed higher values of these bone parameters than athletes with less mechanical impact (e.g., Softball, Swimming). . $9,30^{2}$

Although literature presents a divergent direction in relation to that of the present study when comparing BMC and BMD in different sports, possible justifications for the fact that there is no statistical difference among the different sports can be speculated. In general, this article adjusted analyses by sport training variables (age, weekly training volume and practice time); however, training intensity was not measured in the present study. Thus, depending on the competition cycle of a sport season, the effect of training intensity on bone parameters can be similar, ${ }_{1}^{3}$ which corroborates the results found in this study of lack of differences among sports. Additionally, another justification may be the interference of specific factors in the bone mass of female athletes, such as the use of oral contraceptives, menstrual irregularities, eating disorders. ${ }^{30}$ These factors alone or in combination can alter the quantity and density of bone minerals, as they stimulate osteogenic imbalance, resulting in greater bone resorption (osteoclasts) and, consequently, in lower BMC and BMD, ${ }^{30}$ which when adjusted, differences among sports could be identified.

This study has limitations such: analyses did not discriminate high and low performance players based on the minutes played in competitions; analyses regarding the functions of players in each of the sports were not performed, which could lead to differences in body composition, ${ }^{12,14}$ and variables related to the history of training, injuries and menstrual cycles were not taken into account. The comparison of three body composition components in team sports with different energy requirements is a strong point of this study. The use of precise methods such as PDA and DXA to define body composition parameters is another strong point that should be highlighted. Another strong point was the bias control of DXA measurements, in which the precision error was calculated according to protocol of the International Society for Clinical Densitometry (ISCD) specific for athletes ${ }^{21}$ and, the adjustment of BMC for height, 20 thus ensuring greater data reliability. In addition, the collection procedures for PDA, the sample size, which allowed sufficient statistical power to find differences among sports and the adjustment for covariates related to physical training were other strong points of this study. 


\section{CONCLUSIONS}

It could be concluded that when adjusting models for weekly training volume and practice time, volleyball athletes presented higher FM values compared to Flag Football and Indoor soccer athletes. In addition no significant difference between FFM, BMC/height and total body BMD and sports was found, even after adjusting for training volume and practice time.

Through the results of this study, coaches will be able to learn about FM, FFM, BMC and BMD variations in different sports, which will allow better training control and athletic preparation in the different phases of the sports season. In addition, the difference in FM among sports in female athletes suggests to coaches and other sports performance professionals that this body composition component must be constantly monitored throughout the sports season in order to avoid injuries in athletes of sports such as higher FM (e.g., volleyball) or preventing diseases such as menstrual irregularities, common in athletes who may have low body fat levels (e.g., indoor soccer), which are one of the risk factors for female athlete triad syndrome (i.e., eating disorders, menstrual irregularities and low BMD).

\section{ACKNOWLEDGEMENTS:}

This study was financed in part by the Coordenação de Aperfeiçoamento de Pessoal de Nível Superior - Brasil (CAPES) - Finance Code 001

All authors declare no potential conflict of interest related to this article

AUTHORS' CONTRIBUTIONS: Each author made significant individual contributions to this manuscript. CASAJ, MSM, CSS, GC: substantial contribution to the work concept and design, analysis and interpretation of the work data; writing and critical review of the manuscript and its intellectual content; DASS: writing and critical review of the manuscript and its intellectual content and analysis and interpretation of the work data. All authors reviewed and approved the final version of the manuscript.

\section{REFERENCES}

1. Bilsborough JC, Greenway K, Opar D, Livingstone S, Cordy J, Coutts AJ. The accuracy and precision of DXA for assessing body composition in team sport athletes. J Sports Sci. 2014;32(19):1821-8.

2. Dobrosielski DA, Leppert KM, Knuth ND, Wilder JN, Kovacs L, Lisman PJ. Body composition values of division 1 female athletes derived from dual-energy $x$-ray absorptiometry. J Strength Cond Res. 2019.

3. Bompa T, Buzzichelli C. Periodization Training for Sports. Champaign, IL: Human kinetics; 2015.

4. Sanfilippo J, Krueger D, Heiderscheit B, Binkley N. Dual-Energy X-Ray Absorptiometry body composition in NCAA division I athletes: exploration of mass distribution. Sports Health. 2019;11(5):453-60.

5. Barbieri F, Barbieri R, Queiroga M, Santana W, Kokubun E. Anthropometrical and physiological profile of futsal players of the under-20 and adults categories. Motricidade. 2012;8(4):62-70.

6. Collins RK. Injury patterns in women's intramural flag football. Am J Sports Med. 1987;15(3):238-42.

7. Fields JB, Metoyer CJ, Casey JC, Esco MR, Jagim AR, Jones MT. Comparison of body composition variables across a large sample of national collegiate athletic association women athletes from 6 competitive sports. J Strength Cond Res. 2018;32(9):2452-7.

8. Lidor R, Ziv G. Physical and physiological attributes of female volleyball players-a review. J Strength Cond Res. 2010;24(7):1963-73.

9. Fields JB, Merrigan, JJ, White JB, Jones MT. Body Composition Variables by Sport and Sport-Position in Elite Collegiate Athletes. J Strength Cond Res. 2018;32(11):3153-9.

10. Chu SM, Gustafson KE, Leiszler M. Female athlete triad: clinical evaluation and treatment. Am J Lifestyle Med. 2013;7(6):387-94.

11. Norton K, Olds T. Anthropometrica: a textbook of body measurement for sports and health courses. Sidney: UNSW press; 1996.

12. Dengel DR, Keller KA, Stanforth PR, Oliver JM, Carbuhn A, Bosch TA. Body composition and bone mineral density of division 1 collegiate track and field athletes, a consortium of college athlete research (c-car) study. J Clin Densitom. 2020;23(2):303-13.

13. Peart A, Wadsworth D, Washington J, Oliver G. Body composition assessment in female National Collegiate Athletic Association Division I softball athletes as a function of playing position across a multiyear time frame. J Strength Cond Res. 2019;33(11):3049-55.

14. Stewart A, Ackland T. Anthropometry in physical performance and health. Body composition health and performance in exercise and sport. In: Lukaski HC (ed). Body composition: health and performance in exercise and sport. Boca Raton: CRC Press; 2018. p. 89-108.

15. Cohen J. The t Test for Means. Statistical power analysis for the behavioural sciences. Hillsdale, NJ: Lawrence Erlbaum Associates; 1988.

16. Fields DA, Goran MI, McCrory MA. Body-composition assessment via air-displacement plethysmography in adults and children: a review. Am J. Clin Nutr. 2002;75(3):453-67.
17. Siri WE. Body composition from fluid space and density. In: Brozek J, Hanschel A. Washington, DC: National Academy of Science; 1961.

18. Lazzer S, Bedogni G, Agosti F, De Col A, Mornati D, Sartorio A. Comparison of dual-energy X-ray absorptiometry, air displacement plethysmography and bioelectrical impedance analysis for the assessment of body composition in severely obese Caucasian children and adolescents. Br J Nutr. 2008;100(4):918-24.

19. Cleary J, Daniells S, Okely AD, Batterham M, Nicholls J. Predictive validity of four bioelectrical impedance equations in determining percent fat mass in overweight and obese children. J Am Diet Assoc. 2008;108(1):136-9

20. Nevill AM, Holder RL, Maffulli N, Cheng JCY, Leung SSSF, Lee WTJ, et al. Adjusting bone mass for differences in projected bone area and other confounding variables: an allometric perspective. J Bone Miner Res. 2002;17(4):703-8.

21. Hind K, Slater G, Oldroyd B, Lees M, Thurlow S, Barlow M, et al. Interpretation of dual-energy x-ray absorptiometry-derived body composition change in athletes: a review and recommendations for best practice. J Clin Densitom. 2018;21(3):429-43.

22. Kline RB. Principles and practice of structural equation modeling. Vol 2nd ed. New York City: The Guilford Press; 2005.

23. Cahill S, Jones MT. Measurement of body composition and athletic performance during NCAA-division I women's volleyball and softball seasons. J Strength Cond Res. 2010;24(1):1

24. Blue MN, Hirsch KR, Pihoker AA, Trexler ET, Smith-Ryan AE. Normative fat-free mass index values for a diverse sample of collegiate female athletes. J Sports Sci. 2019;37(15):1741-5.

25. Harty PS, Zabriskie HA, Stecker RA, Currier BS, Moon JM, Jagim AR, et al. Upper and lowe thresholds of fat-free mass index in a large cohort of female collegiate athletes. J Sports Sci. 2019;37(20):2381-8.

26. Sönksen PH, Holt RI, Böhning W, Guha N, Cowan DA, Bartlett C, et al. Why do endocrine profiles in elite athletes differ between sports? Clin Diabetes Endocrinol. 2018;4(1):3.

27. Emslander HC, Sinaki M, Muhs JM, Chao EY, Wahner HW, Bryant SC, et al. Bone mass and muscle strength in female college athletes (runners and swimmers). Mayo Clin Proc. 1998;73(12):1151-60.

28. Whittington J, Schoen E, Labounty LL, Hamdy R, Ramsey MW, Stone ME, et al. Bone mineral density and content of collegiate throwers: influence of maximum strength. J Sports Med Phys Fitness. 2009;49(4):464-73

29. Ackerman KE, Skrinar GS, Medvedova E, Misra M, Miller KK. Estradiol levels predict bone mineral density in male collegiate athletes: A pilot study. Clin Endocrinol (Oxf). 2012;76(3):339-45.

30. Sarkis KS, de Medeiros Pinheiro M, Szejnfeld VL, Martini LA. High bone density and bone health. Endocrino Nutr. 2012;59(3):207-14 